\title{
Knowledge and Governance: a reflection of sustainability from campus to industry
}

\author{
Author: Vania Sarahid Flores Borboa
}

\begin{abstract}
Aim: The author provides a critical reflection of the questionnaire discussed at the workshop "Methodology for assessing the campus sustainability from the perspective of multi-level antifragility" held in June 2016 at the University of Sonora (Hermosillo, Mexico). This paper poses a reflection of how the sustainability perspective in high level education institutions could define the stage of change of alumni and therefore has an influence on sustainability issues of local companies.

Design / Research methods: In the article, the author applies ideas and reflections regarding the research questionnaire discussed at the workshop to sustainability issues in local companies.

Conclusions / findings: Universities have great responsibility in preparing students for applying principles of sustainability into business practice. In particular regarding the complexity of the world, where knowledge can be applied in a quickly changing environment. University staff and students can have a completely different view on the existence of different fragilities.

Originality / value of the article: The article provides critical feedback on an innovative approach towards research on campus sustainability in the context of application to business practice.
\end{abstract}

Keywords: Sustainability, Knowledge, Governance, Stage of Change, perception.

JEL: Q01, B40, 123

$\begin{array}{llr}\text { History: } & \begin{array}{l}\text { received } \\ \text { 2016-12-10, }\end{array} & \text { accepted } \\ \text { 2016-12-16 } & & \end{array}$

\section{Introduction}

In an explorative workshop carried out at the University of Sonora (Hermosillo, Mexico) in June 2016, where both students and staff participated, several issues concerning campus sustainability were discussed. Given the completely explorative nature of this study, no comments, opinions or reflections where considered mistaken, which resulted in a very rich discussion that showed a mind gap between those who are merely 
academics, students who have not entered the labor market yet, and students who already have been working in the industry and now came back to continue their studies. Since all participants were studying or working on projects aimed to contribute to sustainability, they had a purpose in common. However, there existed important differences in their perspective of the problems and potential solutions. In this context, this paper poses a reflection of how the sustainability perspective in high level education institutions could define the stage of change of alumni and in turn influence sustainability issues in local companies.

\section{Reflections}

Considering that five of the goals for sustainable development (e.g., decent work and economic growth, industry innovation and infrastructure, responsible consumption and production) are closely related to industry (United $\mathrm{Na}$ tions 2015), it is of great importance to assess the level at which these organizations are or are not participating to achieve the goals mentioned above. How is this related to campus sustainability? Let us define universities as organizations which provide the world with educated and professionalized individuals, and which will also imprint its values and will somehow define how these individuals will interact and face challenges in their productive life. In this context, two important elements of campus sustainability were emphasized when discussing about how the university values will be imprinted in alumni: knowledge and education, as well as governance. The importance of knowledge and education may seem clear, as they influence and eventually change the way the next generation will face challenges regarding sustainability issues in industry. The relation between university governance, its influence on the mind of students and its impact on sustainability aspects of business may be less clear. According to Commission (2001), governance has been defined to refer to structures and processes that are designed to ensure accountability, transparency, responsiveness, rule of law, stability, equity and inclusiveness, empowerment, and broad-based participation.

Issues of governance were broadly discussed at the workshop. It turned out in the discussion, where 19 students and 7 staff members took part, that perspectives differed completely. While, for example, staff argued there are no small interest groups with much power and there is no authoritarian management style, students disagreed. While it is difficult to assess which group is right, there exists the threat that the opinion of the students influences their mindset. Deeper research on this issue is required, as when there exists the perception of the existence of strong interest groups and an authoritarian management style, this may reduce student participation in discussions and decision-making processes. It also may hamper critical thinking and asking questions, which is relevant for the identification of mistakes. As a consequence, this may lead to a passive attitude at the job after finishing the studies, reducing the capability for identifying fragilities.

The mentioned problems also influence innovation in companies, which is important for sustainability. This not only concerns technology, but also organizational systems. The existence of closed networks of family and friends, as was discussed at the workshop, slow down a company's actions. It provides a message that new ideas and opportunities are not important. This feeling can significantly influence a student's mindset and strengthen the passive attitude as mentioned above, reducing opportunities for companies 
to introduce more sustainable practices. The described problems reduce chances for good governance to develop in companies. It will be difficult to create an atmosphere of participation, collaboration and efficacy in project management; balancing the interest of the stakeholders and the shareholders to those of the community and the environment.

This in turn strengthens problems with misinformation and lack of education in sustainability ideas and values. As a consequence, industrial stakeholders are unlikely to change their lack of interest in improving social responsibility, occupational health and safety conditions, or reducing the direct and indirect environmental effects from their normal operation activities. In other words, the stage of change (Doppelt 2010) is not achieved. It is not possible to obtain a progressive sustainable growth of industry if the stakeholders have no knowledge on what a sustainable business is, or what kind of procedures they should use and apply.

An example will be provided from a case study in a manufacture facility in Hermosillo (Flores 2016). It was found that several sustainability opportunities were not taken into account by the leaders of the organization, not because there were no resources or techniques available. It was because the level of awareness and knowledge was so low that the intention of improving social or environmental impacts of the company never appeared. In informal interviews with stakeholders, during the diagnosis stage of the project, some important declarations were made

"If I had known that, I could have managed to improve it."

Maintenance manager, manufacture facility. This person showed the openness to enter a stage of change, which was hampered by missing information and knowledge. One reason the information of the diagnosis was not produced can be a lack of knowledge, training and/or established strategies to pursue sustainable development. There also could be a serious disturbance in the communications between different departments of the organization. This would then result in the loss of information or the inefficiency of the execution of decisions. In such a case of lack of good governance, it will be hard to apply the preventive measure needed supporting sustainability.

Another interesting statement was made by a production line supervisor. "We do the paper work to accomplish ISO 14001 certification, but we do not really understand what it is for, or we simply quit once we have the certification."

Production line supervisor, manufacture facility

This statement may reflect lack of critical thinking, reflection and knowledge. But it also can be the result of study programs poorly oriented to the labor market and/or business market. While this is only one statement, it shows the relevance of the type of knowledge that is required for the functioning on the labour market. Further research on this issue is recommended to find out whether critical thinking and knowledge on sustainable development is necessary in order to function in a company. When the practice mentioned by the production line supervisor is more common in industry, critical thinking and knowledge is unlikely to be appreciated, as this would require the company to change its practice. When the ISO 14001 certificate is only needed for marketing reasons, any critique would need to be considered in the context of necessary changes, which in turn could lead to costs.

A statement of a production line worker is interesting from the point of view of stakeholder participation, 
empowerment and transparency as elements of good governance.

"I have asked several times to improve the quality of the safety shoes we receive, but no answer has come yet."

Production line work-

er, manufacture facility

In Freeman's (1995) methodology for cleaner production, the importance of the inclusion of every individual in the company's voice is emphasized. In practice, empirical knowledge acquired by workers in field may be very valuable in the process of recognition, analysis and solving of sustainability challenges faced by the industry. Therefore, it is highly recommended to establish a system to register, track and give proper response to every proposal, as well as to implement conditions to promote team work. This should at the same time inspire and encourage continuous participation and will help avoid workshop blindness.

The statements discussed give an idea of the stage of change of these people, which seems to be between pre-contemplation and contemplation, and is at a very low level. There seems to be a poor system of communication in the organization, low inclusion of ideas from people in the lowest positions and the need for training in methodologies to assess sustainability on a daily basis. Awareness campaigns may

\section{Bibliography}

Commission of the European Communities (2001), European governance: a white paper, $\operatorname{COM}(2001)$ 428 final, European Commission, Brussels.

Doppelt B. (2010), The power of sustainable thinking: "How to create a positive future for the climate, the planet, your organization and your life", Kindle Locations 9-10, Taylor and Francis, New York. be implemented, and also team work could be promoted in order to enter a state of action regarding sustainability challenges.

\section{Concluding remarks}

Universities have the task to provide the world with well-prepared and aware professional individuals. Individuals who not only understand differential equations, but also understand the complexity of the world where we are living in. People who understand how economic crisis could lead to self-destruction, chaos, poverty, resource depletion or inequality (contradicting the sustainable development goals). Universities could plant a seed in their students, using principles of good governance, educating and producing knowledge rather than titles, because in a rapidly changing world, knowledge will be needed to deal with new challenges in sustainable development. In this, there lies a challenge that views on reality may differ significantly between students and lecturers. For this reason, discussion, asking question, critical thinking and open-mindedness in the educational process are important. This may create the roots for enabling the introduction of measures by companies for a more sustainable development.

Flores Borboa V.S. (2016), Cleaner production in a manufacture facility, a case of study [Unpublished work].

Freeman H.M. (1995), Pollution prevention handbook, Mc-Graw Hill, New York.

United Nations 2015, Sustainable development knowledge platform. Sustainable development goals, https:// sustainabledevelopment.un.org/?menu $=1300$ [23.10.2016]. 
Wiedza i współrządzenie: przemyślenia nad zrównoważonym rozwojem od kampusu po przemysł
Abstarkt
Cel: Autorka przedstawia krytyczne refleksje dotyczące dyskusji nad kwestio- nariuszem, która odbyła się podczas warsztatów pt. "Methodology for asses- sing the campus sustainability from the perspective of multi-level antifragility" przeprowadzonych w czerwcu 2016 roku na Uniwersytecie w Sonorze (Her- mosillo, Meksyk). Artykuł zawiera przemyślenia związane z pytaniem, w jaki sposób perspektywa zrównoważonego rozwoju w instytucjach edukacji wyż- szej mogłaby definiować stadium zmian absolwentów i w ten sposób oddzia- ływać na kwestie zrównoważonego rozwoju lokalnych przedsiębiorstw.
Uklad / metody badawcze: W artykule autorka odniósł idee i przemyślenia dotyczące kwestionariusza badawczego omawianego podczas warsztatów do problematyki zrównoważonego rozwoju lokalnych przedsiębiorstw.
Wnioski / wyniki: Uniwersytety ponoszą ogromną odpowiedzialność za przygotowywanie studentów do stosowania zasad zrównoważonego rozwoju w praktyce biznesowej, w szczególności w odniesieniu do złożono- ści świata, gdzie wiedza może być zastosowana w szybko zmieniającym się środowisku.
Oryginalność / wartość artykułu: Artykuł prezentuje krytyczne przemyślenia dotyczące innowacyjnego podejścia do badań nad zrównoważonego rozwoju kampusu w kontekście ich zastosowania w praktyce biznesowej.

Słowa kluczowe: zrównoważony rozwój, współrządzenie, stadium zmian, postrzeganie 
Prof. dr hab. Stanisław Czaja (Uniwersytet Ekonomiczny we Wrocławiu)

Prof. dr Wolfgang Gerstlberger (University of Southern Denmark, Odense, Denmark)

Prof. dr hab. Tadeusz Kufel (Uniwersytet Mikołaja Kopernika w Toruniu)

Prof. dr hab. Marek Szydło (Uniwersytet Wrocławski)

Dr hab. Arnnold Bernaciak (Wyższa Szkoła Bankowa w Poznaniu)

Dr hab. Filip Chybalski (Politechnika Łódzka)

Dr hab. inż. Adam Czerwiński (Uniwersytet Opolski)

Dr hab. Karol Kociszewski (Uniwersytet Ekonomiczny we Wrocławiu)

Dr hab. Paweł Kuśmierczyk (Uniwersytet Ekonomiczny we Wrocławiu)

Dr hab. Marta Maciejasz (Uniwersytet Opolski)

Dr hab. Jerzy Marzec (Uniwersytet Ekonomiczny w Krakowie)

Dr hab. Kazimierz Nagody-Mrozowicz (Akademia Wychowania Fizycznego w Katowicach)

Dr hab. Johannes Platje (Wyższa Szkoła Bankowa we Wrocławiu)

Dr hab. Bogusław Półtorak (Uniwersytet Ekonomiczny we Wrocławiu)

Dr hab. Krzysztof Wach (Uniwersytet Ekonomiczny w Krakowie)

Dr Bartosz Bartniczak (Uniwersytet Ekonomiczny we Wrocławiu)

Dr. Diana Cibulskiene (Siauliai University, Litwa)

Dr Grzegorz Cieloch (Wyższa Szkoła Bankowa we Wrocławiu)

Dr Adam Hetmańczuk (Wyższa Szkoła Bankowa we Wrocławiu)

Dr Sebastian Jakubowski (Uniwersytet Wrocławski)

Dr Angelika Kaczmarczyk (Uniwersytet Ekonomiczny we Wrocławiu)

Dr Patrycja Kowalczyk-Rólczyńska (Uniwersytet Ekonomiczny we Wrocławiu)

Dr Agnieszka Krawczyk-Sołtys (Uniwersytet Opolski)

Dr Dominika Malchar (Uniwersytet Opolski)

Dr Waldemar Michalczak (Wyższa Szkoła Bankowa we Wrocławiu)

Dr Monika Paradowska (Uniwersytet Opolski)

Dr Laura Płatkowska-Prokopczyk (Uniwersytet Opolski)

Dr Michał Ptak (Uniwersytet Ekonomiczny we Wrocławiu)

Dr Magdalena Redo (Uniwersytet Mikołaja Kopernika)

Dr Diana Rokita-Poskart (Politechnika Opolska)

Dr Tomasz Rólczyński (Wyższa Szkoła Bankowa we Wrocławiu)

Dr Edyta Szafranek (Uniwersytet Opolski)

Dr Luis Velazquez (University of Sonora, Meksyk)

Dr Markus Will (University of Applied Sciences Zittau/Goerlitz, Niemcy)

Dr inż. Justyna Zygmunt (Politechnika Opolska) 